\title{
THE CONFLICT BETWEEN EXECUTIVE PRIVILEGE AND CONGRESSIONAL OVERSIGHT: THE GORSUCH CONTROVERSY
}

Congress, as the arm of the government responsible for making and overseeing the operation of the nation's laws, has the power to inquire into and review the methods by which those laws are enforced. ${ }^{1}$ Because the executive branch is responsible for enforcing the laws, Congress necessarily requests evidence from that branch. On occasion, the President has sought to protect himself and his officials from congressional overreaching by arguing that the doctrine of executive privilege protects him from conpelled disclosure of inforination or documents. $^{2}$

The President and his officials have asserted this claim frequently. ${ }^{3}$ Most recently, Anne M. Gorsuch, ${ }^{4}$ former Administrator of the Environmental Protection Agency (EPA), claimed an executive privilege when she refused to comply with a subpoena issued in connection with the inquiry of a House of Representatives subcommittee. 5 The subcommittee was investigating the EPA's implementation of the Superfund program for the treatment of hazardous waste sites. As a result of Ms. Gorsuch's refusal to produce the documents, Congress held her in contempt - the first time in United States history that the legislative branch has taken such action against

1. This power is known as oversight or right of inquiry. See infra text accompanying notes 42-55.

2. See infra text accompanying notes 67-99.

3. See Berger, Executive Privilege v. Congressional Inquiry (Part II), 12 UCLA L. REv. 1288, 1333 n.627 (1965). President Eisenhower made one of the most notable claims when he refused to surrender evidence that Senator McCarthy requested in connection with McCarthy's investigation into communism. Eisenhower's claim was one of the boldest assertions by an executive of the right to withhold information from Congress. Id at 1309.

4. On February 12, 1983, shortly before Congress dropped the contempt citation, Ms. Gorsuch reinarried, changing her name to Anne Gorsuch Burford. She is referred to as Ms. Gorsuch throughout this note.

5. Two House subcommittees, the Subcommittee on Investigations and Oversight of the Committee on Public Works and Transportation, and the Subcommittee on Oversight and Investigations of the Committee on Energy and Commerce, sought information froun Ms. Gorsuch. This note will focus on the efforts of the former to obtain documents pertaining to the Superfind. 
the head of an executive agency or department. ${ }^{6}$ Although the President and the subcommittee eventually arrived at a compromise, ${ }^{7}$ this mcident illustrates the historical tension between congressional oversight and executive privilege and highlights the lack of formal methods for resolving such disputes. ${ }^{8}$

This note examines the coinpeting claims of the congressional right to information and the executive's need for secrecy, in liglit of the Gorsuclı dispute. It also suggests inethods for resolving future disputes. The note begins with an overview of the dispute and the eventual coinpromise. 9 It then examines the rights of oversight and executive privilege in nore detail and describes both Ms. Gorsuch's and the House subcommittee's claims under these doctrines. ${ }^{10}$ Finally, it suggests inethods for resolving such interbranch conflicts. ${ }^{11}$ This note argues that compromise is the preferred method; im most cases the involved parties have sufficient incentives to negotiate their differences and should be allowed to do so. Because, in rare instances, a compromise may not be reached, courts inust be ready to settle these clashes, as long as the dispute does not present a nonjusticiable "political" question. The note therefore suggests a framework for the judicial analysis of future disputes.

\section{Congress's CONFrontation WITH THE EPA ADMinistrator}

In 1980, Congress passed the Coinprehensive Environmental Response, Compensation, and Liability Act (CERCLA), ${ }^{12}$ its most recent statutory effort to solve the hazardous waste problem. The Act establishes a 1.6 billion dollar hazardous substance response trust fund, the Superfund, to be used to pay governmental response costs in the amelioration of hazardous waste deposits and spills. ${ }^{13}$ The Act also mandates extensive reporting and recordkeeping requirements for both present and former hazardous waste disposal sites. ${ }^{14}$ The Act requires

6. See Brief for Plaintiff at 2, United States v. House of Representatives, 556 F. Supp. 150 (D.D.C. 1983) [hereinafter cited as Petitioner's Brief].

7. See infra text accoinpanying notes 35-38.

8. See infra text accoinpanying note 104 .

9. See infra notes $12-38$ and accoinpanying text.

10. See infra notes 39-104 and accompanying text.

I1. See infra notes 106-49 and accompanying text.

12. 42 U.S.C. $\S \S 9601-9657$ (Supp. V 1981).

13. 42 U.S.C. $\$ 9631$ (Supp. $V$ 1981). Superfund financing comes largely from excise taxes on companies that generate chemical and petroleuni products and on owners of hazardous waste disposal sites. See I.R.C. $\$ \S 4611-4612,4661-4662$, 4681-4682 (West Supp. 1983). The disposal site tax is used to finance the monitoring and closure of hazardous waste disposal sites that received operating permits. See 42 U.S.C. $§ 9641$ (Supp. V 1981).

14. 42 U.S.C. $\S 9603$ (Supp. V 1981). 
that the President establisl a National Contingency Plan (NCP) to develop procedures for responding to releases of hazardous wastes, for discovering hazardous waste locations, and for evaluating renoval costs and methods. ${ }^{15}$ Additionally, the Act empowers the President to respond to actual or threatened releases of hazardous substances. ${ }^{16}$

On August 14, 1981, President Reagan issued Executive Order 12,316, "Responses to Environmental Damage," which delegated to EPA Administrator Gorsuch the "responsibility for the amendment of the NCP and all of the other functions vested in the President by Section 105" of the CERCLA. ${ }^{17}$ The EPA Administrator thus assumed responsibility for ensuring that parties responsible for abandoned or inoperative hazardous waste sites would clean thein up. ${ }^{18}$

On March 10, 1982, the House Subcominittee on Investigations and Oversight of the Cominittee on Public Works and Transportation began an investigation to determine the inanner in which the EPA was enforcing federal laws addressing the hazardous waste problem, including the CERCLA. ${ }^{19}$ The subcominittee held a field hearing in New York City, in which it received testimony from various local governinent officials, ${ }^{20}$ representatives of citizen groups, ${ }^{21}$ and officials from the United States General Accounting Office. ${ }^{22}$ As a result of this and otleer hearings, ${ }^{23}$ the subcommittee concluded that inany of the liazard-

15. Id. $\S 9605$. Parties responsible for creating hazardous waste sites or chemical spills are hable for: (1) the costs of removal or remedial action incurred by the federal government or state; (2) private response costs consistent with the National Contingency Plan; and (3) damages for injury to natural resources. Id. $\$ 9607$ (a).

16. $I d . \S 9604$. The President may take whatever remedial steps are "necessary to protect the public health or welfare or the environment." Id. $\S 9604(\mathrm{a})(1)$.

17. Exec. Order No. 12,316, 3 C.F.R. 168, 169 (1982).

18. Id.

19. "A central concern in this investigation and review by the Subcommittee was, and continues to be, the efforts being made by the U.S. Environmental Protection Agency to carry out the framework of federal laws that address, in whole or in part, hazardous waste contamination of water resources." H.R. REP. No. 968, 97th Cong., 2d Sess. 7 (1982).

20. The Mayor of Oswego, New York, the town that is the site of the Pollution Abatement Services Company, an abandoned liquid waste incineration operation, expressed concern at the length of time taken to decontaminate that site. Id. at 8 .

21. Residents of Port Washington, N.Y. testified, speculating that large quantities of toxic chemicals may have been illegally disposed of in the community's donnestic waste landfill. Id.

22. A representative from the United States General Accounting Office testified that the EPA's efforts to carry out the Superfund law, including the development of implementing regulations and the National Contingency Plan, were significantly behind schedule, and thus were delaying the rate at which toxic waste sites were being cleaned up. Id.

23. On March 10, 1982, the subcommittee held a hearing in which it reviewed the EPA's previous decision to suspend a restriction on dumping liquid waste im landfills, an action that had raised the possibility that many new "Love Canals" might be created. Id. at 7 . The two EPA officials testifying were unable to provide justification for suspending the ban. Id. On March 17, the EPA announced that it was partially reinstituting the ban. Id. On March 30, 1982, the sub- 
ous waste sites were not being fully, or expeditiously, decontaminated. The subcommittee also found that many of the companies responsible for the wastes were not being held fully liable for their share of the cleanup costs. ${ }^{24}$

The subcommittee sought to review the EPA's Superfund enforcement files in order to determine exactly how the EPA was administering the fund. After unsuccessful atteinpts to obtain these files informally, ${ }^{25}$ the subcommittee authorized subpoenas to be issued to the EPA Administrator and other EPA officials, should they continue to deny the subcommittee access to the disputed enforcement files. ${ }^{26}$

On October 29, 1982, EPA enforcement staff officials refused a subcommittee request to provide access to enforceinent files on three waste sites. ${ }^{27}$ As a result, the House Committee on Public Works and Transportation issucd a subpoena to EPA Administrator Anne M. Gorsuch. The subpoena called for her to appear before the Subcommittee

committee met again to question the same officials further about the landfills. Their testimony conflicted with the earlier testimony, creating suspicion as to whether there had been any need to suspend the ban. See id. at 8 .

24. Id. at 9. As a result of this assessment, the subcommittee conducted additional hearings. Its inquiry, with respect to the Superfund statute, focused heavily on:

Whether there are statutory requirements and/or administrative policies, practices and procedures that affect the government's (EPA's) ability to function effectively and achieve the objectives of the law, or whether amendments to the statute are necded;

Whether the Superfund law's enforcement provisions are being fully and effectively carried out;

Whether adequate efforts have been, or are being made to obtain and/or recovcr the full costs of cleaning up hazardous waste sites from responsible parties;

Whether the Fund, and the existing sources and amounts of revenue for it, particularly the tax on oil and chemicals, is adequate to address both known and potential hazardous waste sites and chemical spills; and

What information is being considered, or not being considered by the EPA, in its administration and management of the Fund, and its execution of responsibilities under Id. the Superfund law.

25. The EPA was less than cooperative with the subcommittee. On Septenber 14, 1982, the subcommittee staff was told that it would have access to the Agency's Region II Superfund enforcement files in New York City. On September 15, the subcommittee staff travelled to New York, but an EPA official there told them that "any of the engineering and technical studics that were being prepared by the several EPA Region II Superfund priority sites could be made available, but that the Subcommittee could not have access to the enforcement files." Id. at 11 . On Septeunber 16, the subcommittee submitted a written request for the documents in dispute to the EPA Administrator and to others in the Agency, in conformance with section 9604(e)(2)(D) of the Superfund law, which requires that "all information reported to or otherwise obtained by the President (or any representative of the President) under this chapter shall be made available, upon written request of any duly authorized committee of the Congress, to such committce." 42 U.S.C. $\S 9604(e)(2)(D)$ (Supp. V 1981). Department of Justice official Stephen Ramsey indicatcd his belief that this section did not give the subcommittee the authority to request the kind of information that they were seeking. H.R. REP. No. 968, 97th Cong., 2d Sess. 13 (1982).

26. H.R. REP. No. 968, 97th Coug., 2d Sess. 13 (1982).

27. See id. at 14. 
on Investigations and Oversight on December 2, 1982 and to produce all books, records, correspondence, memoranda, papers, notes, and documents drawn or received by the Administrator or other EPA officials simce December $11,1980 .{ }^{28}$ In short, the subpoena covered all the pertinent enforcement-related documents concerning the 160 designated Superfund cleanup sites. ${ }^{29}$

Prior to her appearance, Ms. Gorsuch received a ineinorandum from President Reagan instructing her not to make sensitive documents found in active law enforcement files available to Congress or the pubhic except in extraordinary circumstances..$^{30}$ She quoted these instructions im her testimony to the subcommittee and informed it that she would not inake certain requested documents available. ${ }^{31}$ Following her testimony, the subcommittee approved a resolution holding Ms. Gorsuch in contempt. ${ }^{32}$ On December 16, 1982, the full House of Representatives, noting the Administrator's "contumacious conduct," passed a resolution citing Ms. Gorsuch for contempt of Congress. ${ }^{33}$

Although the House action created what soine have termed an "unprecedented constitutional impasse" between the legislative and executive branches of the governunent, ${ }^{34}$ the parties arrived at a colnpromise two months later. On February 18, 1983, subcommittee chairman Levitas and President Reagan agreed to procedures under which subcommittee ineinbers would be allowed to examine the subpoenacd

28. Id. at 33.

29. See id. at 50-53.

30. The memorandum stated that "[b]ecause dissemination of such documents outside the Executive Branch would impair my solemn responsibility to enforce the law, I instruct you and your agency not to furnish copies of this category of docuineuts to the subcommittee in response to their subpoeuas." Memorandum for the Administrator, Environmental Protection Agency (Nov. 30, 1982), reprinted in H.R. REP. No. 968, 97th Cong., 2d Sess. $42-43$ (1982).

31. H.R. REP. No. 968, 97th Coug., 2d Sess. 16 (1982). Administrator Gorsuch explained, however, that more than 750,000 pages of documents would be inade available to the subcommittee. The first five file boxes of such documents were tendered to the subcommittee, but it declined to accept those documents. See Petitioner's Brief, supra note 6, at 14. Ms. Gorsuch also advised the subcommittce that the subpoena as drawn was defective. See H.R. REP. No. 968, 97th Cong., 2d Sess. 17 (1982).

32. The Resolution, approved by a nine to two vote, states:

Be it resolved, That the Subcommittee finds Anne M. Gorsuch, Administrator, U.S. Environineutal Protection Agency, in contempt for failure to comply with the subpoena ordered by this Subcommittee and dated November 16,1982, and the facts of this failure be reported by the Chairman of the Subcommittee on Investigations and Oversight to the Committee on Public Works and Transportation for such action as that Committee deems appropriate.

H.R. REP. No. 968, supra note 19, at 20.

33. H.R. Res. 632, 97th Cong., 2d Sess., I49 CoNg. Rec. H10,040 (daily ed. Dec. 16, 1982). House Resolution 632 was approved 259-105 with 69 members abstaining. Id. at H10,061.

34. Petitioner's Brief, supra note 6, at 1. 
EPA documents. ${ }^{35}$ The subcommittee was to receive edited versions of the requested documents and EPA officials would brief the subcommittee on their contents. ${ }^{36}$ After this initial screening, subcommittee members would be permitted to review the unedited versions of the documents in closed session. ${ }^{37}$ President Reagan hailed the compromise as "consistent with the doctrine of executive privilege while it also assures that necessary information is made available to the Congress." 38

\section{The Tension Between Congressional Oversight and Executive PRIVILEge}

The fact that Congress and the EPA reached a compromise does not diminish the significance of the contempt citation. Congress had never before taken such severe action im order to obtaim imfornation from the executive branch. Yet, although Congress's use of the contempt power was unprecedented, the doctrines that had led to its use were not. The subcommittee and the EPA were properly relying upon the conflicting but well-estabhished rights of oversight and executive privilege.

\section{A. Congress's Claim to the Documents.}

The House subcommittee beheved that it had an absolute right to the requested documents. ${ }^{39}$ The House of Representatives demonstrated its agreement with the subcommittee's position by issumg the contempt citation. Both the subcommittee and the full House recognized that the President was to "take care that the laws be faithfully executed";40 they clainied, however, that this constitutional mandate

35. Final details of the compromise were worked out by Levitas, White House Counsel Fred Fielding, and Deputy Attorney General Edward Schmults. Wash. Post, Feb. 19, 1983, at A1, col. 7.

36. Wash. Post, Feb. 20, 1983, at A1, col. 2.

37. Id. Representative James H. Scheuer, chairman of an Energy and Commerce subcommittee that was also investigating the EPA, explained the need for this circuitous method of disclosure: "This charade was designed as a face saver for the president to get him off the sticky wicket of insisting on executive privilege. We have to go through this hittle dog-and-pony show to get to the unexpurgated, unedited documents . . . . Id.

38. Id. at $\mathrm{A} 12$, col. 2.

39. The subcommittee actually relied on two positions. First it claimed that the CERCLA itself empowered Congress to request this information. See supra note 25. A member of the subcommittee's staff also advised the EPA that "the Subcommittee's inquiry was being pursued under the general authority of the Congress to conduct oversight and investigations, and the rules of the House granting jurisdiction to the Committee and not sinply under the authority granted by Section 104(e)(2)(D) of the Superfund law." H.R. REP. No. 968, 97th Cong., 2d Sess 13 (1982). (footnote omitted).

40. U.S. CoNST. art. II, $\$ 3$. 
empowered the President and his aides only to carry out the laws enacted by Congress and did not authorize those executive officials to withhold documents necessary for Congress to oversee the operation of the laws. ${ }^{41}$

1. The History of Congressional Oversight. The subcommittee was relymg upon its oversight authority when it subpoenaed the EPA documents. Congress's right to inquire is essentially the right to conduct imvestigations relevant to its legislative functions. ${ }^{42}$ Congress may conduct investigations into departments of the federal government as well as, $m$ some instances, the affairs of private citizens. ${ }^{43}$ It may also request information pursuant to these investigations. ${ }^{44}$

Several theories underhe the notion of congressional oversight. The first is that the public is entitled to be informed of the workings of its government. ${ }^{45}$ Congress must therefore be able to determine how federal laws are operating in order to be able to report to its constituents. ${ }^{46}$ Second, Congress must be able to investigate in order to determine whether remedial legislation is needed. ${ }^{47}$ Third, Congress's exercise of oversight protects the liberties of the American people by serving as a check on unbridled executive power. Congress, by "acquainting itself with the acts and dispositions of the administrative agents of the Government," 48 will be able to uncover corruption, waste, inefficiency, and rigidity ${ }^{49}$ and to ensure that the President is enforcing the laws as enacted by Congress.

41. See H.R. ReP. No. 968, 97th Cong., 2d Sess. 10-11 (1982).

42. See Watkins v. United States, 354 U.S. 178, 187 (1957).

The power of Congress to conduct investigations is inherent in the legislative process. That power is broad. It encompasses inquiries concerning the administration of existing laws as well as proposed or possibly needed statutes. It includes surveys of defects in our social, economic or political system for the purpose of enabling the Congress to remedy them. It comprehends probes into departments of the Federal Governinent to expose Id. corruption, inefficiency or waste.

43. "There is no general authority to expose the private affairs of individuals without justification in terms of the function of the Congress." Id. at 187 (eniphasis added).

44. See McGrain v. Daugherty, 273 U.S. 135, 174 (1927). "Article I's grant of power to legislate is therefore held to carry implied authority to summon witnesses and to compel the production of evidence." Cox, Executive Privilege, 122 U. PA. L. Rev. 1383, 1385 (1974).

45. Watkins v. United States, 354 U.S. 178, 200 (1957).

46. President Wilson considered this function to be extrenely important: "The informing function of Congress should be preferred even to its legislative function." W. WILSON, CONGRESSIONAL GOVERNMENT 297, 303 (1913), quoted in Watkins v. United States, 354 U.S. I78, 200 n.33 (1957).

47. Watkins v. United States, 354 U.S. 178, 187 (1957).

48. Berger, The Incarnation of Executive Privilege, 22 UCLA L. Rev. 4, 10 (1974)(quoting W. Wilson, CONGRESSIONAL GOVERMMENT 297, 303 (1913)).

49. See infra note 148 and accompanying text. 
The Supreme Court has described Congress's oversight authority as "an essential and appropriate auxiliary to the legislative function." 50 The Court has, however, placed some limitations upon this power..$^{51}$ First, pursuant to the separation of powers doctrine, Congress may not reach into the "exclusive province" of the executive branch.52 Second, exercise of the investigative power must be related to a legitimate legislative task of Congress; 53 there is no congressional power to expose inerely for the sake of exposure. ${ }^{54}$ These limitations, however, are not unduly restrictive and leave Congress a great deal of freedom to determine whether the executive branch is properly enforcing the laws. ${ }^{55}$

2. The Subcommittee's Claims for the EPA Documents. The subcommittee believed that it was properly invoking its oversight authority in the Gorsuch dispute. It maintamed that it had undertaken its

50. McGrain v. Daugherty, 273 U.S. 135, 174 (1927). Here, the Court was reviewing the propriety of a Senate committee investigation into charges that the Department of Justice had failed to prosecute public corruption, antitrust violations, and other inatters relating to the handling of several oil leases. The Court upheld the inquiry as a proper exercise of the legislative function. Id. at 180 .

51. Some commentators have argued that Congress's oversight authority is, in fact, absolute. See, e.g., R. Berger, Executive Privilege: A Constitutional MYth (1974). Mr. Berger looked "to the Constitution and its history" rather than to recent practice to determine the scope of congressioual control over information, id. at 10 , and found that the power to inquire is absolute. Id. at 36-37.

52. Barenblatt v. United States, 360 U.S. 109, $111-12$ (1959). The separation of powers doctrine imposes this limitation on the oversight power. This doctrine was created by the framers of the Constitution, who considered the combination of powers of government to be "the very definition of tyranny." THE FedERALIST No. 47, at 336 (J. Madison)(Wright ed. 1961). James Madison expressed his fear that the "legislative department is everywhere extending the sphere of its activity, and drawing all power into its impetuous vortex." THE FEDERALIST No. 48, at 333 (J. Madison)(J. Cooke ed. 1961). The separation of powers doctrine suggests that when the congressional power of inquiry is directed at the executive branch, it cannot interfere with the executive duties.

53. Watkins v. United States, 354 U.S. 178, 187, 197 (1957). Watkins specifically mentions the restraints of the Bill of Rights upon congressional investigations. Id. at 198.

The Supreme Court used this restriction to invalidate a House investigation into a private real estate pool that was part of the financial structure of J. Cook \& Co. The United States had deposited funds with the company, which went bankrupt. Congress believed that the pool was coimected with the bankruptcy. The Court found the mquiry to be judicial in nature because the investigation "could result in no valid legislation on the subject to which the inquiry referred." Kilbourn v. Thompson, 103 U.S. 168, 192-97 (1881). The Court therefore held the inquiry to be in excess of the investigative power conferred on the House by the Constitution. Id. at 192.

54. Watkins v. United States, 354 U.S. 178, 200 (1957).

55. Needless to say, congressional oversight produces beneficial results when used properly. In 1927, a Senate committee investigation led to the discovery of the Teapot Doune scandal. See Berger, Executive Privilege v. Congressional Inquiry (Part I), 12 UCLA L. REv. 1044, 1049 (1965); 149 CoNG. REc. H10,052 (daily ed. Dec. 16, 1982)(remarks of Rep. Dingell); see also McGrain v. Daugherty, 273 U.S. 135, 177-78 (1927)(Court permitted congressional investigation into enforcement decisions of the Department of Justice). 
investigation in order to determine whether the EPA was properly administering the hazardous waste laws. ${ }^{56}$ Many members of Congress and the public believed that the Reagan Administration and the EPA were not carrying out Congress's inandate to aggressively decontaminate the nation's hazardous waste sites. ${ }^{57}$ Congress was concerned, therefore, that the Reagan Administration was subverting the intent of the Superfund laws by enforcing them half-heartedly.

In addition to reports of low morale at the EPA, Congress had received specific charges of impropriety. EPA officials alleged that the Administrator had allowed political considerations to enter into her enforcement decisions. ${ }^{58}$ The subcominittee also suspected the EPA of giving hazardous waste polluters lenient settlement terms. ${ }^{59}$

The subcominittee believed that the requested documents would

56. The subcommittee also argued that the documents were necessary if Congress was to make an informed decision whether to alter or repeal the CERCLA when it expires in 1985. 149 CONG. REC. H10,033 (daily ed. Dec. 16, 1982).

57. As the New York Times explained the contempt citation against Administrator Gorsuch, the "immediate cause was her refusal to hand over documents about EPA's clean-up enforcement efforts. The underlying reason for the House's unprecedented action is its belief that lier agency is simply uninterested in doing anything about the country's myriad Love Canals, except to claim success and let them fester." N.Y. Times, Dec. 28, 1982, at A22, col. 2.

The New York Times also stated that "the Reagan Administration, in its eagerness to ease the burden of government regulation imposed on industry, had embarked on a systennatic reversal of decades of progress in the national effort to protect human health and natural resources froin environmental degradation." Shabecoff, Forecast for E.P.A. Was Stormy From the Start, N.Y. Times, Feb. 20, 1983, $\$ 4$ (The Week in Review), at 2, cols. 4-5.

58. Three EPA officials charged that clean-up of the Stringfellow site in California was held up until after the November, 1982 California senatorial election for fear that then-Governor EdInund G. Brown, Jr. might take credit for obtaining the federal funding and thereby benefit his cainpaign for the Senate. Russakoff, White House Acts in EPA Controversy, Wasl. Post, Feb. 10, 1983, at A6, col. 6. Stating that "[p]olitical considerations have not driven any decisions" in the hazardous waste program, Ms. Gorsuch explained that it took time for the EPA to calculate California's contribution to the cleanup, and to decide whether the agency should commence contributing to the cleanup, or bring suit against the polluters first. See id. A Justice Department investigation into the charges found a lack of evidence to implicate Ms. Gorsuch. See San Francisco Examiner, Aug. 11, 1983, at A6, col. 1.

59. The subcommittee believed that two "sweetheart deals" may have been arranged between the EPA and busmesses in violation of the CERCLA.

(1) In the fall of 1982, the EPA agreed to a private scttlement for the cleanup of a facility of the Seymour Recycling Corporation near Seymour, Indiana. The settlement, which was concluded over the strong objections of EPA General Counsel Robert M. Perry, may enable 24 major compames to avoid millions of dollars of liability. See Wash. Post, Feb. 10, 1983, at A1, col. 2.

(2) In August, 1982, the EPA announced a settlement agreement involving the Chem-Dyne Corporation dumpsite in Hamilton, Ohio; 112 compames agreed to contribute a total of $\$ 12.3$ million for surface clcanup. The EPA filed a lawsuit against 16 other firms that refused the settlement terms. Critics noted that "the clean-up covered surface contamination only, and that the 112 companies, which settled for an average of just over $\$ 20,000$ each, will face no further liability if contamination later is found in groundwater or sub-surface soil." Wash. Post, Feb. 8, 1983, at A4, col. 3. 
help it determine whether the EPA was properly enforcing the law. ${ }^{60}$ These documents would reveal what factors the EPA was and, perhaps more importantly, was not considering in making enforcement decisions. ${ }^{61}$ This inforination would clarify the EPA's Superfund enforcement strategy, a significant indicator of how closely the agency had followed its congressional mandate. Furthermore, the subcommittee beheved that the documents would reveal whether any of the specific charges of impropriety were true. Thus, Congress argued that the investigation was related to a legitimate legislative concern ${ }^{62}$ and was a proper exercise of its oversight authority. ${ }^{63}$ If so, it follows that the subcommittee had the power to coinpel disclosure of the requested documents, unless the exercise of that power was constrained by some other legal doctrine.

\section{B. The EPA's Position.}

Balanced against the subcommittee's exercise of the congressional oversight power was the President's claim that Congress was interfering with the executive responsibility to "take care that the laws be faithfully executed." 64 Congress contended that this responsibility could not protect an administrative agency against compelled disclosure. ${ }^{65}$ The EPA, however, contended that it was entitled, under the doctrine of executive privilege, to withhold information if disclosure would imterfere with the executive's constitutional duties with regard to enforcement of the laws. ${ }^{66}$

1. The History of Executive Privilege. The EPA's claim of executive privilege was neither novel nor surprising. Congress, in pursuing its oversight duties, seeks much of its evidence froin the executive branch. Courts have interpreted Congress's power of inquiry to require

60. H.R. REP. No. 968, 97th Cong., 2d Sess. 45 (1982).

61. Id. at 20. As the subcommittee explained: "[We] must be able to examine how and why the agency is making its decision to enforce, or not to enforce, to litigate or not to litigate, to settle or not settle with some, or all of the parties that may be involved im the various Superfund cases." Id.

The General Counsel to the Clerk of the House analogized to the congressional right upheld by the Supreme Court in McGrain v. Daughterty, 273 U.S. 135, 174 (1927), see supra note 50. He maintained that the right to examine and inquire into specific enforcement decisions within the Department of Justice "applies with equal, if not greater, force to the Environmental Protection Agency." H.R. ReP. No. 968, 97th Cong., 2d Sess. 59 (1982).

62. See supra note 53 and accompanying text.

63. See 149 Cong. REc. H10,052 (daily ed. Dec. 16, 1982) (statement of Rep. Dingell).

64. U.S. CoNST. art. II, $\$ 3$.

65. See supra text accoinpanying note 41.

66. See 149 Cong. REc. H10,055 (daily ed. Dec. 16, 1982)(statement of Rep. Dannemeyer); Petitioner's Brief, supra note 6, at 55. 
disclosure of executive documents. ${ }^{67}$ Nevertheless, cabinet officials have invoked the doctrine of executive privilege to withstand both legislative and judicial probing. ${ }^{68}$ The rationale behind the doctrine is that in certain instances disclosure would either significantly impair the perfornance of the constitutional responsibilities ${ }^{69}$ of the executive branch or interfere with its functioning as an independent branch of the government. ${ }^{70}$ When disclosure would cause such harm, the executive branch and its officials must be exempt front the disclosure requirements.

Although a claim of executive privilege was raised as early as $1796,{ }^{71}$ the Supreme Court did not recognize a constitutional foundation for the privilege until 1974. In United States v. Nixon, ${ }^{72}$ the Court stated that "to the extent this interest [President Nixon's interest in withholding incriminatimg tapes] relates to the effective discharge of the President's powers, it is constitutionally based." 73 The Nixon Court recognized that executive privilege was a byproduct of the separation

67. Cox, supra note 44 , at $1385-86$.

68. For a general discussion of the scope of executive privilege, see J. NowAK, R. RotUNDA \& J.N. Young, Constitutional LAW 224-30 (2d ed. 1983).

69. Underlying this consideration is a concern that without the privilege, officials would be unwilling to engage in frank, open discussion for fear of later reprisals. As the United States District Court for the District of Columbia noted, "the privilege subserves a preponderating policy of frank expression and discussion among those upon whom rests the responsibility for making the determination that enables government to operate." Carl v. Zeiss Stiftung v. V.E.B. Carl Zeiss, Jena, 40 F.R.D. 318, 324 (D.D.C. 1966)(footnotes omitted).

70. The Supreme Court recognized this argument as support for the privilege. See infra note 74 and accompanying text. President Washington voiced this argument in his Farewell Address:

It is important, likewise, that the habits of thinking in a free country slould inspire caution in those entrusted with its administration to confine theinselves within their respective constitutional spleres, avoiding in the exercise of the powers of one departinent to encroach upon another. The spirit of encroachunent tends to consolidate the powers of all the departments in one, and thus to create, whatever the form of government, a real despotisin.

Speech of President George Washington, Sept. 17, 1796, quoted in Younger, Congressional Investigations and Executive Secrecy: A Study in the Separation of Powers, 22 U. PITT. L. Rev. 755, 758 (1959).

71. President Washington had invoked this doctrine just five months prior to his farewell speech when lie refused to turn over papers requested by a House committee forned to examine the failure of a military campaign against the Indians. He maintained that the House had no right to those documents, as they related to matters exclusively within the executive's domain. Younger, supra note 70 , at 758 .

72. 418 U.S. 683 (1974). The case arose out of the now infamous Watergate investigation. The Special Prosecutor had issued a subpoena directing the President to produce tape recordings and documents relating to his conversations with aides and advisors. The documents were requested following the imdictment of a number of White House staff members and supporters for violations of federal statutes. President Nixon claimed executive privilege and filed a motion to quasl the subpoena. Although the Supreme Court denied the motion, it recognized an executive privilege. The Court held, however, that the privilege was not absolute. Id. at 706.

73. Id. at 711 . 
of powers doctrine; 74 if Congress were allowed to inquire into every area of the executive's province it could exert improper influence upon the President's power. The Court also suggested that the privilege could be readily inferred from article $\mathrm{II},{ }^{75}$ the constitutional provision that outlines the executive's duties. Confidentiality is necessary for the President to properly carry out his responsibilities, because it fosters the free flow of inforination and candor necessary for effective decisionmaking. ${ }^{76}$

The Nixon opinion recognized that the privilege was not absolute. The Court held that "[ $[\mathrm{t}]$ he generalized assertion of privilege must yield to the demonstrated, specific need for evidence in a pending criminal trial."77 The opinion was, however, somewhat vague as to when executive privilege would give way to legislative probing. The highest deference is to be given to claims of executive privilege for inilitary and diplomatic secrets. The Court stated that

Absent a claim of need to protect military, diplomatic, or sensitive national security secrets, we find it difficult to accept the argument that even the very important imterest in confidentiality of Presidential communications is significantly diminished by production of such inaterial for in camera inspection with all the protection that a district court will be obliged to provide. ${ }^{78}$

The Nixon Court did not state that executive privilege was never applicable to protect information other than that which inuplicates national security. Presidential communications are "presumptively privileged"; $; 9$ there is, however, no high degree of deference due a presidential assertion of privilege when there is only a generalized executive interest in confidentiality. ${ }^{80}$ Instead the Court seemed to iniply that the President, in order to prevail on his privilege clainl, had to denıonstrate convincingly that confidentiality would be compronised. ${ }^{81}$

74. Id. at 706.

75. See id. at 707 .

76. Id. 708 .

77. Id. at 713 .

78. Id. at 706; see Henkin, Executive Privilege: Mr. Nixon Loses But The Presidency Largely Prevails, 22 UCLA L. REv. 40, 44 (1974).

79. Nixon, 418 U.S. at 708.

80. Id at 711 .

81. See id. The Nixon Court's opinion has been criticized, in part, for its failure to establish clear guidelines for future disputes. See Mishkin, Great Cases and Soft Law: A Comment on United States v. Nixon, 22 UCLA L. REv. 76, 91 (1974).

Two Watergate era cases decided by the United States Court of Appeals for the District of Columbia Circuit help to illuminate the factors considered by courts in executive privilege cases. In Nixon v. Sirica, 487 F.2d 700 (D.C. Cir. 1973), the court determined that the presumption of privilege premised on the public interest in confidentiahty failed in the face of a powerful showing inade by the Special Prosecutor of a vital need for the President to produce certain tape recordings pursuant to a grand jury subpoena duces tecun. The court applied a balancing test, stating that 
The Nixon opinion was concerned with the use of the privilege "as against a subpoena essential to enforcement of criminal statutes," 82 and the way the privilege interfered with the judiciary's ability to "do justice in criminal prosecutions." 83 The Court exphicitly rejected the notion that it was addressing the balance between the President's generalized interest in confidentiality and congressional demands for information. ${ }^{84}$ "The opinion nonetheless lends some support to the

the "application of Executive privilege depends on a weighing of the public interest protected by the privilege against the public interest that would be served by disclosure in a particular case." Id. at 716; see also Nixon v. Administrator of Gen. Servs., 433 U.S. 425, 443 (1977)(in determining whether the proper balance between the coordinate branches has been upset, the proper inquiry focuses on the extent to which the executive branch is prevented froin accoinplishing its constitutionally assigned functions); Association for Women in Science v. Califano, 566 F.2d 339, 346 (D.C. Cir. 1977)(executive privilege upheld as the government requirement of secrecy was "the more compelling need"). The Nixon v. Sirica court empliasized that the grand jury

is not engaged in a general fishing expedition, nor does it seek in any way to investigate the wisdom of the President's discharge of his discretionary duties. On the contrary, the grand jury seeks evidence that may well be conclusive to its decisions in on-going investigations that are entirely within the proper scope of its authority.

487 F.2d at 717 .

Although a grand jury proceeding assures the confidentiality of executive officials' testimony and of agency documents, closed congressional committee ineetings can probably approximate the secrecy of the grand jury. The second Watergate era case, Senate Select Comm. v. Nixon, 498 F.2d 725 (D.C. Cir. 1974), dealt with an executive refusal to hand over documents subpoenaed by a congressional committee. The court determined that the need demonstrated by the Senate Select Committee on Presidential Campaign Activities for some of President Nixon's tapes was "too attenuated and too tangential to its functions to permit a judicial judgment that the President is required to coinply with the Committee's subpoena." Id. at 733. The court noted that the conmittee could point "to no specific legislative decisions that cannot responsibly be made without access to materials uniquely contained in the tapes or without resolution of the anbiguities that the transcripts may contain." Id. The subpoenaed materials were in the possession of the House Judiciary Committee and there was no showing that the Select Committee needed access of its own. Id. The Senate Select Committee opinion noted "the presunption that the public interest favors confidentiality," which "can be defeated only by a strong showing of need by another institution of government-a showing that the responsibilities of that institution cannot responsibly be fulfilled without access to records of the President's deliberations." Id. at 730.

It has been suggested that executive branch officials should have to make a stronger showing to invoke executive privilege when there are accusations of executive wrongdoing. See Ratner, Executive Privilege, Self-Incrimination, and the Separation of Powers Illustration, 22 UCLA L. REv. 92, 104 (1974). Nevertheless, the propriety of a congressional demand for material inust finally turn on the "nature and appropriateness of the function in performance of which the material was sought, and the degree to which the inaterial was necessary to its fulfillment." Senate Select Comm., $498 \mathrm{~F} .2 \mathrm{~d}$ at 731 . Certainly the inquiry into possible executive wrongdoing is an appropriate function of Congress, and the executive branch will lose its clain of privilege if a House committee can show that "subpoenaed evidence is deinonstrably critical to the responsible fulfillment of the Committee's functions." Id. The court suggests that it will be more difficult for a congressional committee to demonstrate the requisite need to overcome executive privilege than it would be for a grand jury to do so. Id. at 732 .

82. 418 U.S. at 707.

83. Id.

84. The Nixon Court stated: 
proposition that the President may, in certain circumstances, withhold information from the Congress." 85

Professor Laurence Tribe has classified presidential refusals to furnish information as three distinct executive privileges, derived from three distmct considerations. ${ }^{86}$ First, presidents have invoked executive privilege in order to protect military or diplomatic secrets. ${ }^{87}$ Second, the law of evidence includes an informer's privilege-" "the Governnient's privilege to withhold from disclosure the identity of persons who furmish information of violations of law to officers charged with enforcement of that law."88 Third, courts recognize a privilege extending to "intra-governmental documents reflecting advisory opinions, recommendations and deliberations comprising part of a process by which governmental decisions and policies are formulated." 89

In the Gorsuch dispute the latter two types of executive privilege were at issue. The EPA documents concerned law enforcement files that might contain information of EPA's secret informants. The files also contamed intra-agency nemos and recommendations that EPA personnel compiled for use in making Superfund enforcement pohicy and decisions.

In the Gorsuch dispute, an agency director invoked the privilege, but she did so at the express request of the chief executive. Executive privilege extends to agency officials, but it may not apply with force equal to that afforded the President's personal assertion of the privilege. In United States $v$. Reynolds, ${ }^{90}$ the Court stated that the privilege belongs to the government, and nuust be asserted in a formal claim

\footnotetext{
We are not here concerned with the balance between the President's generalized interest in confidentiality and the need for relevant evidence in civil litigation, nor with that between the confidentiality interest and congressional demands for information, nor with the President's interest in preserving state secrets. We address only the conflict bctween the President's assertion of a generalized privilege of confidentiality and the constitutional need for relevant evidence in criminal trials.

Id. at 711 n.19.

85. L. Tribe, American Constitutional Law $\$ 4-15$ n.1 (1978); see also Henkin, supra note 78 , at 43 .

86. L. TRIBE, supra note $85, \S 4-14$.

87. See, e.g., New York Times Co. v. United States, 403 U.S. 713, 728-30 (1971)(Stewart, J. concurring)(Pentagon Papers Case).

88. See, e.g., Rovario v. United States, 353 U.S. 53, 59 (1957).

89. See, e.g., Carl Zeiss Stiftung v. V.E.B. Carl Zeiss, Jena, 40 F.R.D. 318, 324 (D.D.C. 1966)(various applications of executive privilege listed by the court, 40 F.R.D. at 324 n.15).

The Supreme Court in NLRB v. Sears Roebuck \& Co., 421 U.S. 149 (1975), noted that the ultimate purpose of this long-recognized privilege is to prevent injury to the quality of agency decisious. The quality of a particular agency decision will clearly be affected by the cominunications received by the decision-maker on the subject of the decision between predecisional communications, which are privileged, and communications designed to explain a decision already inade, which are not. Id. at 151.
}

90. 345 U.S. 1 (1953). 
lodged by the head of the department that has control over the matter ${ }^{91}$ "after personal consideration by that officer." 92

Two recent cases interpreting the extent of executive immunity from civil liability may offer some insight imto whether executive privilege becomes less compelling when asserted by a cabimet neinber instead of the President. In Nixon v. Fitzgerald, ${ }^{93}$ the Supreme Court held that "a former President of the United States is entitled to absolute immunity from damages liability predicated on his official acts. We consider this immunity a functionally mandated incident of the President's unique office, rooted in the constitutional tradition of the separation of powers and supported by our history."94 This absolute immunity exists at least where Congress has not expressly subjected the President to civil liability for his official acts. ${ }^{95}$ Yet, in the companion case, Harlow v. Fitzgerald, ${ }^{96}$ the Court found only a qualified immunity for semior presidential aides and advisers. When these officials claim absolute immunity they "first nust show that the responsibilities of [their] office embraced a function so sensitive as to require a total shield from liability." 97 The strength of a derivative claim to presidential immunity thus depends upon the executive function invoked; the claim would be strongest when made by presidential "alter egos" working in

91. Id. at 7-8.

92. The Reynolds court explained that the "essential matter is that the decision to object should be taken by the minister who is the political head of the department, and that he should have seen and considered the contents of the documents and himself have formed the view that on grounds of public interest they ought not to be produced." Id. at $8 \mathrm{n.20}$ (citing Duncan v. Cammell, Laird \& Co., 1942 A.C. 624, 638 (H.L.)).

93. 457 U.S. 731 (1982).

94. $I d$. at 749 .

95. The Court noted that granting the President absolute immunity did not remove all constraints upon his power to act:

There remains the constitutional remedy of impeachment. In addition, there are formal and informal checks on Presidential action that do not apply with equal force to other executive officials. The President is subjected to constant scrutiny by the press. Vigilant oversight by Congress also may serve to deter Presidential abuses of office, as well as to make credible the threat of impeachment. Other incentives to avoid misconduct inay include a desire to earn re-election, the need to inaintain prestige as an eleinent of Presidential influence, and a President's traditional concern for his historical stature.

The existence of alternative remedies and deterrents establislies that absolute immunity will not place the President "above the law." For the President, as for judges and prosecutors, absolute immunity merely precludes a particular private remedy for alleged misconduct in order to advance compelling publie ends.

Id. at 757-58 (footnotes omitted).

96. 457 U.S. 800 (1982).

97. Id. at 812-13. The Harlow Court also concluded that "government officials performing discretionary functions generally are shielded from liability for civil damages insofar as their conduct does not violate clearly established statutory or constitutional rights of which a reasonable person would have known." Id. at 818. See also Butz v. Economou, 438 U.S. 478, 506 (1978)("federal officials who seek absolute exemption from personal liability for unconstitutional conduct must bear the burden of showing that publie policy requires an exemption of that scope"). 
such exclusively executive domams as foreign policy and national security. ${ }^{98}$ The EPA cleanup function does not qualify as such a sensitive, exclusively executive responsibility. Thus, although Administrator Gorsuch had a claim of executive privilege available to her, the privilege did not provide an absolute shield.

\section{The Executive Branch's Arguments Against Disclosing The Doc-} uments. The EPA contended that disclosure of the documents would have a deleterious effect on pending investigations ${ }^{99}$ and interfere with its ability to administer the Superfund. ${ }^{100}$ These were, in fact, valid concerns. ${ }^{101}$ Many of the documents concerned cases in the early stages of investigation, where disclosure could be particularly harmful. Revealing the information ${ }^{102}$ could forewarn depositors of hazardous wastes that they were suspected of illegal activity. Disclosure would also place the EPA at a disadvantage in settleinent negotiations with these violators. The requested files included: the EPA's proposed settlement strategies, lists of potential witnesses, detailed descriptions of available evidence, anticipated defenses, the elements of proof required im a given case, the legal issues involved, and the possible precedential impact of certain rulings. If this information became public, the targets of the investigations would know the EPA's bottom-line settlement po-

98. 457 U.S. at $812 \mathrm{nn} .18-19$.

99. As Attomey General Smith explained in a letter to Representative John Dingell, "[t]he Executive cannot effectively investigate if Congress is, in a sense, a partner in the investigation. If a congressional committee is fully appraised of all details of an investigation as the investigation proceeds, there is a substantial danger that congressional pressures will influence the course of the investigation." Letter to Hon. John H. Dingell, Chairman, Subcommittee on Oversight and lnvestigations, Committee on Energy and Commerce, House of Representatives, Washington, D.C., (Nov. 30, 1982), reprinted in H.R. REP. No. 968, 97th Cong., 2d Sess. 37-38 (1982).

100. See 149 CoNG. REC. H10,055 (daily ed. Dec. 16, 1982) (statement of Rep. Dannemeyer); Petitioner's Brief, supra note 6, at 55.

101. The Reagan Administration's additional fears about the precedeutial effect of full acquiescence to the congressional subpoena, on the other hand, were highly speculative. The Adininistration worried that President Reagan's willingness to accommodate Congress in this instance might make it harder for future presidents to resist demands for enforcement documents relating to areas outside the environmental protection field. See 149 CoNG. REC. H10,057-58 (daily ed. Dec. 16, 1982)(statement of Rep. Clausen).

102. The Reagan Administration had good reason for concern that information in the withheld documents might reach unintended parties. As Joseph Bishop, deputy geueral counsel of the Army froin July, 1952 to October, 1953, noted, "there can be no guarantee that information coining into the hands of Congress or the whole inembership of one of its major committees will long remain secret. . . . Even legislators of high respectability have been known, in the heat of partisan passion, to place the national interest a very poor second to considerations of faction." Bishop used, as an exainple, an incident taking place in 1941 when Senator Burton K. Wheeler, an isolationist, had revealed the Navy's oceupation of Iceland while the operation was still in progress and the ships involved were vulnerable to attack. Bishop, The Executive's Right to Privacy: An Unresolved Constitutional Question, 66 Y ALE L.J. 477, 487 \& n.41 (1957). 
sition, its negotiation strategy, and the agency's perception of the strengths and weaknesses of its case. ${ }^{103}$ This information might enable a violator to negotiate a nore favorable settlenent. Finally, public disclosure of the documents would make it easier for violators to defend themselves against lawsuits.

Thus, both the subcommittee and the EPA had valid claims to the documents. Neither the legislative nor the executive branch has guidelines for resolving such coinpeting claims. As one Congressinan noted during the debate preceding the conteinpt vote, "the Supreine Court has yet to be called upon to resolve the question of the respective rights of the executive and legislative branches im regard to a claim of privilege as a defense to coinpulsory legislative process for docuinents residing within the Executive Branch."104 Because both parties believed that they had an absolute claim to the docuinents, a settleinent was slow to einerge.

\section{ANAlysis for Future Disputes}

The Gorsuclı dispute was by no means sui generis. It is likely that this problem will recur. In order to avoid confrontations more severe than that involving Ms. Gorsuch, this note suggests guidelines for weighing the colnpeting claims of the legislative and executive branches.

\section{A. Compromise Between the Branches.}

Despite the political question doctrime, the judiciary is often available as the final arbiter in interbranch disputes. Judicial solutions should, however, be a last resort; ${ }^{105}$ parties should be encouraged to resolve their differences outside of court, as in the Gorsuch dispute.

103. Petitioner's Brief, supra note 6 , at 67.

104. 149 Cong. ReC. H10,042 (daily ed. Dec. 16, 1982)(statement of Rep. Solomon).

105. In fact, the United States District Court for the District of Columbia demonstrated this restraint in the Gorsuch controversy. The Government had asked the court to declare that Ms. Gorsuch had acted lawfully in refusing to release the requested documents. The court refused. It stated:

Courts have a duty to avoid unnecessarily deciding constitutional issues. . . . When constitutional disputes arise concerning the respective powers of the Legislative and Executive Branches, judicial mtervention should be delayed until all possibilities for settlement have been exhausted. . . Judicial restraint is essential to maintain the delicate balance of powers among the branches established by Constitution. . . . Since the controversy which has led to United States $v$. House of Representatives clearly raises difficult constitutional questions in the context of an intragovernmental dispute, the Court should not address these issues until circumstances mdicate that judicial imtervention is necessary.

United States v. House of Representatives, 556 F. Supp. 150, 152-53 (D.D.C. 1983)(citation omitted). 
Most disputes are susceptible to compromise, ${ }^{106}$ and this is the preferred method of resolution.

Informal compromise has several advantages relative to judicial resolution. First, courts are not well equipped to evaluate the conflicting claims of the executive and legislative branches. They have no expertise in weighing the Congress's legislative needs against the President's political imperatives. ${ }^{107}$ A court ruling in a particular dispute might hamstring either the President or Congress during future disputes in perhaps inarkedly different pohtical environments. For example, such a ruling might unduly limit Congress's ability to investigate. As one scholar has noted:

The need for access to executive papers and communications arises too seldom in traditional forms of civil or criminal proceeding for the judicial rulings to have much impact upon the effectiveness of the Presidency, but the occasions upon which Congress may demand information are virtually unlimited. Any binding definition of the power of the Senate or House of Representatives to obtain the internal communications of the Executive Branch and of the President to withhold them might greatly affect the relative political power and effectiveness of the Executive and Legislative Branches. ${ }^{108}$

Compromise, as a method of resolution, has worked well in the past. The courts have been hesitant to resolve struggles between the President and Congress, yet Congress has managed to compel the President to hand over information on many occasions. ${ }^{109}$ Congress has powerful political weapons capable of compelling disclosure. ${ }^{110}$ It controls appropriations and legislation ${ }^{111}$ and, perhaps inost sigmificantly, commands inedia attention ${ }^{112}$ and with it the ability to mobilize public opinion against the executive. Congress may also obtain information througl the now-established device of a special prosecutor, and

106. Cf. Exxon Corp. v. FTC, 589 F.2d 582, 589 (D.C. Cir. 1978)("The courts must presume that the committees of Congress will exercise their powers responsibly and with due regard for the rights of affected parties.").

107. Paul J. Mishkin, speaking of United States v. Nixon, contended that the "fundamental evil is that the Court was confronted with the issue. The basic failing was that the problem was not resolved by the political system, imcluding the other two branches of government, before it reached the Court." Mishkin, supra note 81, at 91.

108. Cox, supra note 44 , at $1425-26$.

109. See id. at 1431.

110. See id. at 1431-32; Berger, supra note 3, at 1320 .

111. Bishop, supra note 102 , at 486 .

112. For an example of newspaper reaction to the contempt citation against Gorsuch, see $A n$ Unnecessary Face-Off, L. A. Times, Dec. 19, 1982, at V-4, col. 1 ("considering Gorsucl's record as the administrator of EPA, it is fair to say that her resistance to disclosure of the documents may have more to do with lack of enforcement than with a theoretical danger of harming the agency's enforcement efforts"). See also The Superfund Turned Upside Down, N.Y. Times, Dec. 28, 1982, at A22, col. 1 . 
through its more drastic powers to issue contempt citations ${ }^{113}$ and institute impeachment proceedings. Congress's willingness to use such weapons ensures that the executive will not lightly reject a congressional request for information.

Finally, the imprecision of the demarcation line between conflicting claims of executive secrecy and congressional inquiry encourages both parties to seek a compromise. "Neither the executive nor the Congress is very sure of its rights and both usually evince a tactful disposition not to push the assertion of their rights to abusive extremes. Of such is the system of checks and balances." 114

The Gorsuch dispute itself is a good example of how effective these forces can be in inducing a compromise. Congress appeared eager to rush into an unseemly confrontation with the executive branch without having fully explored the opportunities for reaching a compromise. ${ }^{115}$ The House subcommittee issued a perhaps unnecessarily broad ${ }^{116}$ subpoena and did not review the material that Ms. Gorsuch was prepared to turn over prior to undertaking a contempt proceeding agamst her. Yet despite its apparent intransigence, the subcommittee

\section{Professor Bishop notes that:}

Congress undoubtedly has power to punish contempts without invoking the aid of the executive and the judiciary, by the simple forthright process of causing the Sergeant at Arms to seize the offender and clap him in the common jail of the District of Columbia or the guard room of the Capital Police.

Bishop, supra note 102, at 484 . In fact, such action was threatened by congressional counsel Stanley M. Brand. See Chi. Trib., Feb. 2, 1983, at 14, col. 1.

114. Bishop, supra note 102, at 491.

115. The members of the Committee on Public Works and Transportation who did not support the recommendation that Administrator Gorsuch be cited for contempt of Congress noted that "[t]he Committee did not exhaust all means of resolving the dispute before resorting to the contempt citation." H.R. REP. No. 968, 97th Cong., 2d Sess. 73 (1982)(mmority views). The dissenting members cited several examples:

First, prior to the Full Committee meeting, White House officials asked to meet with the Full Committee Chairman and Ranking Minority Member. The meeting was not held.

Second, White House officials offered to show the Chairman and Ranking Minority Member a sampling of the withheld documents so that they would better understand the Administration's position on this matter. This overture was rejected.

Third, a compromise proposal was offered which would have given the U.S. District Court in the District of Columbia the jurisdiction to determine the validity of the Subcommittee's subpoena. White House officials indicated that the Administration would not only support this legislation but would work in the House and Senate to enact it during the lameduck session. This proposal was rejected.

And fourth, the Administration, in responding to a compromise proposal made by the Subcommittee Chairman, offered a counter proposal in a letter dated Deeember 9 1982. No formal response was made to the Administration's proposal prior to the Full Committee meeting to cite Ms. Gorsuch for contempt.

Id. at 74.

116. Representative Michel stated that the subpoena, which covered more than 750,000 pages of EPA documents, "looked like it was based on a fishing expedition." 149 CONG. REC. H10,047 (daily ed. Dec. 16, 1982). 
eventually compromised. Both sides were placated and the national hazardous waste disposal effort benefitted.

\section{B. Judicial Resolution of the Dispute.}

Although interbranch conflicts are best resolved by compromise, courts must be prepared to act when the two branches are unwilling to settle their differences. When a stalemate occurs, ${ }^{117}$ the judiciary may have to intervene to avoid "detrimental effects on the smooth functioning of government." 118

1. The Political Question Doctrine. The potential necessity for intervention raises the problem of whether a court can resolve such a dispute. The Gorsuch controversy appears, at first glance, to be of the type defined by the Supreme Court as a "political question" and to be therefore nonjusticiable. "The political question doctrine-which holds that certain matters are really political in nature and best resolved by the body politic rather than suitable for judicial review-is a misnomer."119 The political question doctrine is more aptly characterized as a doctrine of nonjusticiability that applies when the subject matter in dispute is inappropriate for judicial consideration. ${ }^{120}$ Nevertheless, the Supreine Court often renders decisions in cases involving "pohtical" issues. The Court has fashioned the following test for determining whether the doctrine should be mvoked:

Prominent on the surface of any case held to involve . . . [a] political question is found a textually deinonstrable constitutional commitment of the issue to a coordinate political department; or a lack of judicially discoverable and manageable standards for resolving it; or the impossibility of deciding without an initial policy determination of a kind clearly for nonjudicial discretion; or the impossibility of a court's undertaking independent resolution without exprcssing lack of the respect due coordimate branches of government; or an unusual need for unquestioning adherence to a political decision already made; or the potentiality of embarrassment from multifarious pronouncements by various departments on one question. ${ }^{121}$

In United States v. Nixon, Chief Justice Burger rejected the arguinent that President Nixon's claim of executive privilege presented a political question, because the controversy in that case was one that the courts traditionally resolve under their article 11I power: the production or

117. See, e.g., Drinan v. Nixon, 364 F. Supp. 854, 858 (D. Mass. 1973).

118. United States v. AT\&T, 567 F.2d 121, 126 (D.C. Cir. 1977).

119. J. NowAK, R. RotUNDA \& J.N. Young, supra note 68, at 109.

120. Id.

121. Baker v. Carr, 369 U.S. 186, 217 (1962). 
nonproduction of specified evidence that the prosecutor deemed relevant to and admissible in a pending criminal case. ${ }^{122}$

It is not certain that the Gorsuch controversy would have qualified as a nonjusticiable question. ${ }^{123}$ Raoul Berger has argued:

Neither the Congress nor the nation can be content to have the executive branch finally draw constitutional boundaries when the consequence is seriously to impair a legislative function that is so vital to the democratic process. No more may Congress decide the scope of Executive power. Neither Branch, in Madison's words, has the "superior right of settling the boundaries between their respective powers." That power was given to the courts." 124

A court would likely consider the Gorsuch case to be closely analogous to United States $v$. Nixon. In both cases the President sought to deny information from an investigating body, be it court or congressional committee, on the basis of executive privilege. Congress's subpoenas and the rules governing their enforcement do not substantially differ froin their judicial counterparts. Admittedly, Congress has its own independent mechanisms for enforcing its processes. Yet the Nixon Court's decision not to invoke the political question doctrine did not depend on the specific processes available to courts for enforcement of their subpoenas. ${ }^{125}$ Instead the court was concerned with the presence of judicially manageable standards, standards that would not be dramatically affected if the requesting body were a congressional committee rather than a court. ${ }^{126}$

122. 418 U.S. at $696-97$. In a case presenting a classic nonjusticiable political question, the court declined to hear a petitioner seeking an end to the Vietnam War. See Drinan v. Nixon, 364 F. Supp. 854 (D. Mass. 1973). Such a case is readily distinguishable from the Gorsuch controversy.

123. The District Court seemed to have confronted this issue. In refusing to issue a declaratory judgment, the court noted, "the Judicial Brancl will be required to resolve the dispute by determining the validity of the Administrator's claim of executive privilege" should the parties be unable to coinpromise. United States v. House of Representatives, 556 F. Supp. 150, 152 (D.D.C. 1983).

124. Berger, supra note 3, at 1361-62; see Nixon v. Sirica, 487 F.2d 700, 715 (D.C.Cir. 1973).

125. Cf. United States v. House of Representatives, 556 F. Supp. 150, 153 (D.D.C. 1983)("Judicial resolution of this coustitutional claim . . . will never beconne necessary unless Administrator Gorsuch becomes a defendant in either a criminal contempt proceeding or other legal action taken by Congress.").

126. Soune commentators remain concerned that future disputes between Congress and the executive branch might raise nonjusticiable questions unless some furtler action is taken. One commentator suggests:

What is needed is a new statute that would provide the federal courts with undisputed jurisdiction to hear a suit brought by Congress to enforce its subpoenas to executive branch officials; [sic] require that executive officials proinptly answer Congress' coinplaimt, and require that the courts, imcluding the Supreme Court, give the case expeditious treatinent.

Hamilton, Settling Inter-Branch Disputes, New Haven Register, Feb. 8, 1983, at 7, col. 1; see also Berger, Executive Privilege v. Congressional Inquiry, 12 UCLA L. REv. 1288, 1361-62 (1965); Cox, supra note 44 , at $1432-35$ (1974). 
2. A Framework for Analyzing Future Disputes. Once a court has satisfied itself that it is not faced with a nonjusticiable issue, it can proceed to the merits of the claim. In analyzing a collision between Congress and the executive branch, a court must first assure itself that both the oversight power and executive privilege are being properly asserted. Congress must be undertaking a legitimate legislative function and the executive branch must be correct that the information is of a type traditionally considered to be privileged. Once the court has made this determination it must determine which claim should prevail. Although the Supreme Court has neither resolved a dispute similar to the Gorsuch controversy nor provided a franework for doing so, the lower courts have developed a test that would be apphicable here. In Nixon v. Sirica, ${ }^{127}$ the Umited States Court of Appeals for the District of Columbia Circuit stated that a judge, im reviewing a claim for executive privilege, must balance the public interest protected by the privilege agaimst the interests that would be served by disclosure of particular information. ${ }^{128}$ One year later that same court suggested, in Senate Select Committee v. Nixon, ${ }^{129}$ that in weighing these interests a court should begin with a presumption in favor of confidentiahty. 130 Congress would then have to rebut the presumption by demonstrating a compelling and specific need for the disputed materials. ${ }^{131}$ If Congress satisfied its burden, the court would order disclosure.

In evaluating coinpeting claims, the court must first dccide how much weight to accord the presuinption in favor of executive privilege. To do so, it must evaluate the type of information being requested. Military and diplomatic secrets have been considered absolutely privileged, ${ }^{132}$ so that, no inatter how coinpelling the case for disclosure, Congress will probably never be able to satisfy its burden. ${ }^{133}$ Interoffice memoranda, although presumptively privileged, are not given the absolute protection afforded military secrets. Although the Supreme Court in United States $v$. Nixon ${ }^{134}$ noted the importance of maintainimg confidentiahty, ${ }^{135}$ the Court also stated that "we cannot conclude that

127. 487 F.2d 700 (D.C. Cir. 1973).

128. Id. at 716 .

129. 498 F.2d 725 (D.C. Cir. 1974).

130. Id. at 730 .

131. Id.

132. See supra text accompanying note 78 .

133. See United States v. Reynolds, 345 U.S. 1, 11 (1952)("Where there is a strong showing of necessity, the claim of privilege should not be lightly accepted, but even the most compelling necessity cannot overcome the claim of privilege if the court is ultimately satisfied that military secrets are at stake.")

134. 418 U.S. 683 (1974).

135. Id. at 705; see also supra text accompanying note 76 . 
advisers will be moved to temper the candor of their remarks by the infrequent occasions of disclosure because of the possibility that such conversations will be called for in the context of a criminal prosecution."136 Admittedly, a civil investigation may imphicate different concerns than a criminal proceeding and a court should take these differences into account; a court, however, should do so in light of the assumption that such documents are not granted the highest degree of protection possible.

In determining the weight to accord to a claim of executive privilege, a court should also take into account any relevant statutes. These may indicate congressional recognition, not only that a claim of executive privilege exists in certain areas, but that there is a public interest that would be served by protecting confidentiahty. The Court of Appeals for the District of Columbia Circuit utilized this method of analysis in Black v. Sheraton Corp. of America. ${ }^{137}$ It reviewed a request for law enforcement documents. In evaluating a claim of executive privilege, the court assessed whether there was a public interest in minimizing disclosure. ${ }^{138}$ It noted that the Freedom of Information Act, which compels the disclosure of a number of government documents, provides an exemption for documents similar to those requested by the House subcommittee. ${ }^{139}$ The court stated that this exemption enbodied a congressional recognition of the necessity for the privilege, ${ }^{140}$ and it took this conclusion into account in determining whether the plaintiff, in this case a private party, had satisfied its burden of demonstrating an interest outweighing the confidentiality interest. ${ }^{141}$

Finally, a court evaluating a claim of privilege should also consider the identity of the party asserting that claim. As noted previously, ${ }^{142}$ the strength of the privilege nnay be diminished when a cabinet official asserts its protection, as coinpared to an assertion by the President himself.

136. 418 U.S. at 712 .

137. 564 F.2d 531 (D.C. Cir. 1977). In Sheraton, the plaintiff was a private lobbyist affiliated with Robert Baker, Secretary to the Majority of the Senate. Black was indicted, and ultimately convicted, on incoine tax evasion charges. He claimed that both the indictment and his subsequent difficulty obtaining new employment were caused by government dissemination of information collected by an illegal eavesdrop. He sought discovery, under the Freedom of Information Act, of certain documents associated with the prosecution. The government refused to disclose several of the documents, except to a district court in camera.

138. Id. at $545-46$.

139. Id. at 546; see 5 U.S.C. $\$ 552(b)(7)$ (1982) (exemption for "investigatory records coinpiled for law enforcement purposes").

140. 564 F.2d at 546.

141. Id at 547.

142. See supra text accompanying notes 91-98. 
The court unust consider these factors in light of the interests asserted by Congress. As the Supreme Court stated in United States $v$. Nixon, ${ }^{143}$ a "demonstrated, specific need" for material may be found to be more compelling than a general assertion of executive privilege. ${ }^{144}$ The degree of specificity is not the only factor relevant to a court's inquiry. The court should also examine the underlying interest that Congress seeks to protect. For mstance, when Congress voices a convincing concern that the health of inhabitants of certain communities is in imminent danger, its request for documents should be accorded greater deference than a request for inaterials regarding the use of tax money to build public highways. In other words, the magnitude of the danger and its probability are both relevant concerns.

In striking the balance between Congress and the President, a court inust be concerned with how nuch the disclosure would impair or disrupt the President's ability to carry out his consitutional duties. If necessary, the court should establish a systein of procedural safeguards to ensure that Congress's access to the documents will be accomplished with minimal infringement on the President's article II powers. For instance, a court could conduct an in canera inspection of the documents. ${ }^{145}$ Such private examination would allow a judge to release only those documents necessary to the legislative duty to inquire into the operation of the laws, while minimizing the release of documents genuinely harmful to the presidency. Such a procedure, however, might impose huge burdens on particular federal judges, who would be required to sort putatively privileged material to determine which documents are relevant to Congress's inquiry. As a less burdensome remedy, a court could require that Congress receive the sensitive materials only in executive session, a measure that would promote confidentiality. ${ }^{146}$

143. 418 U.S. 683 (1974).

144. Id. at 713 .

145. See id. at 730; $c f$. Carl Zeiss Stiftung v. V.E.B. Carl Zeiss, Jena, 40 F.R.D. 318, 330-33 (D.D.C. 1966). "The ultimate question is whether, in the circumstances of the case, the occasion for assertion of the privilege is appropriate. In camera inspection is not an end in itself, but only a method that may in given instances be indispensable to decision of that question." Id. at 332. See generally United States v. Reynolds, 345 U.S. 1 (1952).

146. Under the analysis suggested in this note, judicial resolution of the Gorsuch matter would have led to the release of the Superfund enforcement documents. The President's assertion of executive privilege would have created a presumption in favor of applying the privilege. The presuniption would not have been insurmountable, however. First, the docunients were not inilitary secrets and were therefore not accorded absolute protection. Second, the privilege was being asserted by a cabinet official, not by the President. Congress's showing of a specific legislative need to inquire into the operation of CERCLA and into allegations of governmental wrongdoing would then have defeated the presumption in favor of the privilege and would have justificd a court order requiring the EPA to turn over the disputed docunients to the subcommittee. But, in 
In utilizing this note's suggested framework for resolving this type of dispute, the courts will be able to maintain the necessary balance between the need for full congressional inquiry into the operation of the laws and the legitimate requirements of secrecy in the executive branch. The courts must protect the integrity of the administrative process from mere unfocused curiosity. ${ }^{147}$ For exainple, few would condone congressional demands made to the Justice Department for transcripts of testimony to a grand jury obtamed as part of an ongoing investigation into organized crime. Thus, executive confidentiality in some circumstances must be protected. Yet Congress must be able to guard against governmental deception ${ }^{148}$ and to exercise its oversight authority. Its rights should not be limited merely because the President asserts that certain information should not be disclosed. ${ }^{149}$ The suggested shifting burden test takes the President's concerns into account. If a court assumes that executive officials have the privilege to withhold information whenever Congress is unable to demonstrate otherwise, the court protects administrators and relieves them from the anomaly of having to make public the reasons for keeping certain information private. Yet such a test does not unduly circumscribe congressional power. In instances where the information is necessary, and requested pursuant to a legitimate legislative need, such as when Congress is

view of the demonstrated executive need to keep enforcement documents secret, the reviewing court would have been obliged to provide for special procedures that would minimize the infringement on executive duties and powers by preventing improper disclosure of the documents.

147. See United States v. Morgan, 313 U.S. 409 (1941). In Morgan, the Supreme Court lield that a court could not depose the Secretary of Agriculture regarding the process by which he determined the maximum rates to be charged by narket agencies for their services at the Kansas City stockyards, because "the integrity of the administrative process unust be . . respected." Id. at 422; see also Cox, supra note 44, at 1429. Raoul Berger unakes a distinction between a privilege for "secrets of the cabinet" and

an unlimited discretion to withhold any document or commumications between the several million subordimate employees in the interest of "administrative efficiency." . . . The two are incommensurable. An assumption that information may be concealed from Congress on the plea of "administrative efficiency" would have shielded Fall, Denby and Daugherty from congressional investigation and have enabled thein to despoil the nation of Teapot Doine, and all in the guise of taking "care that the Laws be faithfully executed!"

Berger, supra note 3, at 1289-90.

148. As Cox explained, the "claim of privilege is a useful way of hiding inefficiency, naladministration, breach of trust or corruption, and also a variety of potentially controversial executive practices not authorized by Congress." Cox, supra note 44, at 1433. He also noted that the "central problem today is how to deal with governmental secrecy and . . . with governmental deception." Id. at 1434 .

149. As the Court of Appeals for the District of Columbia Circuit stated in Nixon v. Sirica, "although the views of the Chief Executive on whether his Executive privilege should obtain are properly given the greatest weight and deference, they cannot be conclusive." 487 F.2d 700, 716 (D.C. Cir. 1973). 
properly using its oversight authority, the court will compel disclosure. In short, the integrity of both branches can be preserved.

\section{CONCLUSION}

Congress's citation for conteinpt of EPA Administrator Anne Gorsuch illustrates a recurring problem in American constitutional history: the clash between the congressional right to inquire into the operation of the laws and the executive right to secrecy in intradepartmental communications--specifically the secrecy of law enforcement records and intra-agency recommendations. Congress's oversight power has long been recognized as an incident of the constitutional grant of legislative power. Executive privilege is based on the need for confidentiality of executive communications and is implied by the separation of powers doctrine. Neither congressional oversight nor executive secrecy is absolute, and it is inevitable that the two doctrines will conflict with one another froin time to time.

The two branches should first attempt to resolve any conflict on their own. When compromise is not forthcoming, and a court is not precluded by the political question doctrine from adjudicating the dispute, judicial resolution of a dispute may be necessary in order to end governmental staleinate. In such a case, the court should employ a balancing test that presumes that the executive branch should not ordinarily be compelled to disclose infornation regarding sensitive matters such as national security affairs and pending law enforcement decisions. Congress may defeat the presuinption only if it can demonstrate a specific legislative need. Such an arrangement will assure the integrity of both branches and prevent stalemate in our federal system.

Ronald L. Claveloux 